\title{
Effect of interesterification on glyceride structure
}

\author{
By Y. El-Shattory and Saadia M. Aly \\ Fats and Oils Dept., National Research Centre, Dokki, Cairo, Egypt.
}

\section{RESUMEN}

Efecto de la interesterificación sobre la estructura glicerídica.

Se ha llevado a cabo el proceso de interesterificación en aceite de soja - ácido oleico ( $2: 1 \mathrm{w} / \mathrm{w})$ a diferentes concentraciones de níquel como catalizador $(0.4$ y $0.6 \%)$, a una temperatura de $90^{\circ} \mathrm{C}$ y a un tiempo de batido de 4 horas. La hidrólisis de la estructura glicerídica individual se hizo usando lipasa pancreática para obtener 2-monoglicéridos. El cálculo se llevó a cabo para determinar la estructura glicerídica del aceite de soja interesterificado.

PALABRAS-CLAVE: Aceite de soja - Acido oleico - Glicérido (estructura) - Interesterificación - Níquel.

\section{SUMMARY}

\section{Effect of interesterification on glyceride structure}

Interesterification process on soybean oil - oleic acid (2:1 w/W $)$ was carried out under different concentration of nickel catalyst $(0.4$ and $0.6 \%$ ), at temperature $90^{\circ} \mathrm{C}$ and stirring for 4 hours. The hydrolysis of individual glyceride structure was done using pancreatic lipase to obtain 2-monoglycerides. Calculation was recorded to determine the glyceride structure of the interesterified soybean oil.

KEY-WORDS: Glyceride (structure) - Interesterification Nickel - Oleic acid - Soybean oil.

\section{INTRODUCTION}

Interesterification is a process that is used to modify the structure and composition of oils and fats to improve their physical and nutritional properties $(1,2)$. Conventionally, the interesterification reaction is promoted by sodium metal or sodium alkoxide to catalyze acyl migration between triglyceride molecules and to produce randomly distributed fatty acyl residues among the triglyceride molecules (3).

In recent year, the use of lipases as biocatalysts for interesterification reactions has become of great industrial interest for the production of useful triglyceride mixtures. This is mainly because of the specificity of these enzymes with respect to glyceride positions and fatty acid types (4). Lipases are known to catalyze mild esterification reaction with the formation of specific compounds that are easy to isolate without molecular distillation (5).
Akoh and co-workers (6) described synthesis of monoglycerides in organic solvent by lipase. This enzyme successfully catalyzed the esterification of glycerol with oleic acid or eicosapentanoic acid (EPA) in hexane. The pancreatic lipase, which possesses near absolute specificity for hydrolysis of the sn 1,3 position in triglycerides, shows a difference in the distribution pattern of fatty acids in the resulting 2-monoglycerides of interesterified and hydrogenated fats. The pancreatic lipolysis method, followed by examination of the fatty acids of the 2-monoglycerides, is a method for detecting an interesterified fat (7).

Lipase can be used in several ways in the modification of triglycerides. The physical properties of naturally occurring triglycerides depend not only on saturation or unsaturation of the attached acyl groups, but also on the position of these groups. In chemical interesterification, it is difficult to introduce the desired acyl group into the desired position on glycerol because the reaction occurs randomly (8).

Mottson and Lutton (9) studied the specific distribution of the fatty acids in the glyceride of animal and vegetable fats by means of pancreatic lipase, which removed $\alpha$-substituted fatty acids predominently.

One application of the lipase catalyzed interesterification of triglycerides which has been studied is the preparation of cocoa butter equivalents. Normally the starting material is palm oil mid fraction and the purpose of the lipase catalyzed reaction is to introduce more stearate into the triglycerides of the palm oil mid fraction. The main component of palm oil mid fraction is the triglyceride 1,3 dipalmitoyl2-oleoyl-glycerol (POP), which can be converted to 1-palmitoyl-2-oleoyl-3-stearoyl-glycerol and 1,3-distearoyl2-oleoyl-glycerol by the interesterification reaction. The result is a fat with a triglyceride composition resembling cocoa butter which can be used as cocoa butter equivalent in the chocolate and confectionary industry. As it is the fatty acids in position 1 and 3 which should be replaced, the 1,3 specific lipases are the enzymes of choice the reaction medium normally consist of a mixture of the triglyceride to be converted and the stearate component either as free acid or an ester, in a nonpolar organic solvent (10). 
In this article of work the glyceride structure of interesterified soybean oil under different conditions of temperature, time of stirring and nickel catalyst percentages will be investigated in an attempt to give a clear picture on its fatty acids distribution in comparison with soybean oil.

\section{MATERIALS AND METHODS}

- Bleached soybean oil and oleic acid were obtained from Cairo Company for Oils and Soaps.

- Chemical interesterification was carried out with different concentration of nickel catalyst ( 0.4 and $0.6 \%$ ) at $90^{\circ} \mathrm{C}$ and 4 hours of stirring. Soybean oil and oleic acid were in the ratio $2: 1 \mathrm{w} / \mathrm{w}$.

- Source of lipase: pancreatic lipase was obtained from Sigma Chemical Company.

Procedure for lipase hydrolysis:

Hydrolysis of triglyceride fractions was carried out to obtain the 2-monoglyceride (11).

Approximately $1.0 \mathrm{gm}$ of interesterified soybean oil was transferred to a tipped bottom flask, and the temperature was adjusted to $40^{\circ} \pm 0.5^{\circ} \mathrm{C}$. To the sample, $10 \mathrm{ml}$ of $1.2 \mathrm{M}$ ammonium chloride-ammonia hydroxide $\left(\mathrm{NH}_{4} \mathrm{Cl}-\mathrm{NH}_{4} \mathrm{OH}\right)$ buffer, adjusted to $\mathrm{pH}$, $8.5,2 \mathrm{ml}(22 \%, \mathrm{w} / \mathrm{v})$ solution of calcium chloride hexahydrate and $0.1 \mathrm{ml}$ of a $25 \% \mathrm{w} / \mathrm{v}$ solution of bile salt sodium taurocholate were added. Pancreatic lipase $(0.3$ gram) was added with stirring and the $\mathrm{pH}$ was maintained at 8.5 during hydrolysis. After 30 minutes about 60 or $70 \%$ of original natural triglyceride was converted into 2-monoglyceride. Then the reaction was stopped by the addition of $4 \mathrm{~N}$ hydrochloric acid to bring the $\mathrm{pH}$ to 1.0 . The reaction mixture was extracted with diethyl ether and the ethereal solution was dried over anhydrous sodium sulphate, filtered and evaporated under reduced pressure. The 2-monoglycerides were separated from the other lipids and free fatty acid by preparative thin layer chromatography (12) on silica gel $\mathrm{G}$ with hexane and diethyl ether (60:40).

The 2-monoglycerides were extracted with chloroform and then convert to methyl esters according to Metcalfo and Schmitz (13) and were examined by gas liquid chromatography under these conditions:

- Adual flame ionization detector Varian 3700 , with packed column $20 \%$ diethylene glycol succinate (DEGS) on chromosorb W 60-80 mesh. The column length 6 feet with internal diameter $1 / 8$ inch, carrier gas flow rate $(\mathrm{He}) 30 \mathrm{ml} / \mathrm{min}$., hydrogen flow rate 30 $\mathrm{ml} / \mathrm{min}$ and air flow rate $300 \mathrm{ml} / \mathrm{min}$.

- Column temperature $190^{\circ} \mathrm{C}$ injection temperature $220^{\circ} \mathrm{C}$, detector temperature $300^{\circ} \mathrm{C}$.

\section{RESULTS AND DISCUSSION}

Concerning the study the fatty acid constituents of soybean oil before interesterification (control) and after carrying the reaction at $90^{\circ} \mathrm{C}$ for four hours of stirring using 0.4 and $0.6 \%$ nickel catalyst as well as those of the 2-monoglycerides obtained by lipase hydrolysis are recorded in table I. We trace that linoleic and linolenic acids of interesterified soybean oil samples and their 2-monoglycerides are decreased comparing to the control samples. Whereas oleic and stearic acids are increased in interesterified oil while oleic is decreased and stearic is increased in 2-monoglycerides of the interesterified samples. This means that the fatty acid composition of the 2-monoglycerides are different from those of the corresponding whole triglycerides which agree with the view of Roy and Bhattacharyya (7).

Table I

Fatty acid composition percentages of soybean oil (control) and interesterified oils at $90^{\circ} \mathrm{C}$ for 4 hours of stirring using 0.4 and $0.6 \%$ nickel catalyst and their monoglycerides

\begin{tabular}{ccccccc}
\hline \multirow{2}{*}{$\begin{array}{c}\text { Fatty } \\
\text { acid }\end{array}$} & Soy oil (control) & $\begin{array}{c}\text { Interesterified soy oil } \\
\text { using } 0.4 \% \text { nickel } \\
\text { catalyst }\end{array}$ & $\begin{array}{c}\text { Interesterified soy oil } \\
\text { using } 0.6 \% \text { nickel } \\
\text { catalyst }\end{array}$ \\
\cline { 2 - 7 } & Oil & Monoglyceride & Oil & Monoglyceride & Oil & Monoglyceride \\
\hline $\mathrm{C}_{16: 0}$ & 15.0 & 2.67 & 10.8 & 29.6 & 12.0 & 32.1 \\
$\mathrm{C}_{18: 0}$ & 9.2 & 20.3 & 36.4 & 23.4 & 39.6 & 22.9 \\
$\mathrm{C}_{18: 1}$ & 20.8 & 57.1 & 43.6 & 41.2 & 39.2 & 38.9 \\
$\mathrm{C}_{18: 2}$ & 46.4 & 11.7 & 6.1 & 2.6 & 5.3 & 3.1 \\
$\mathrm{C}_{18: 3}$ & 8.2 & 6.2 & 3.1 & 2.9 & 3.9 & 2.8 \\
\hline
\end{tabular}

The results recorded in tables $\|-V$ showed the 2-monoglycerides regarding the type of glycerides. We notice that 2-olein glycerides with stearin at 1 and/or 3-positions are more than that of 2-stearin glycerides with olein at 1-and/or 3-positions, while 2-linolein with linolenolein at 1-and/or 3-positions and vice versa are small quantities. This mean that the 2-monoglycerides produced by pancreatic lipase hydrolysis of soybean oil triglycerides contain mostly $\mathrm{C}_{18}$ unsaturated fatty acids (11) and the remaining fatty acids are randomly distributed among sn 1,3-positions of the triglycerides and these findings are in accord with the positional distribution theory suggested by Van Der Wal (15), Coleman and Fulton (14), Cunstone (16), Youngs (17), Roy and Bhattacharayya (7). Table VI, showed the triglyceride percentages in terms of the four main glyceride categories, namely trisaturated $\left(\mathrm{GS}_{3}\right)$, disaturated $\left(\mathrm{GS}_{2} \mathrm{U}\right)$, monosaturated $\left(G U_{2}\right)$ for the interesterified soybean oil samples. It is clear that the $\mathrm{GS}_{3}$ values is 11.707 and $13.209 \%$ 
using 0.4 and $0.6 \%$ nickel catalyst, respectively, which is lower than the expected one when correlated to the content of total saturated fatty acids $\left(\mathrm{C}_{16: 0}\right.$ and $\left.\mathrm{C}_{18: 0}\right)$ of interesterified soybean oil samples about $54 \%$ table $\mathrm{I}$. This fact agrees with the findings of Kartha (18-21) concerning restricted random distribution theory. The formation of trisaturated glycerides is believed to be due to the presence of saturated fatty acids in the 2-position (10) 1,2-diglycerides are chemically unstable, and therefore they undergo either spontaneously or enzymatically added acyl migration to form 1,3 diglycerides $(22,23)$.

Table II

2-mono-stearin with olein at 1-and/or 3-positions percentages

\begin{tabular}{cccc}
\hline $\begin{array}{c}\text { Type of } \\
\text { glycerides }\end{array}$ & Control & $\begin{array}{c}\text { S.O. interesterified } \\
\text { for } 4 \text { hours } \\
\text { at } 90^{\circ} \mathrm{C} \text { with } 0.4 \% \\
\text { nickel catalyst }\end{array}$ & $\begin{array}{c}\text { S.0. interesterified } \\
\text { for } 4 \text { hours } \\
\text { at } 90^{\circ} \mathrm{C} \text { with } 0.6 \% \\
\text { nickel catalyst }\end{array}$ \\
\hline S S S & 0.018 & 4.95 & 5.06 \\
S S OI & $0.016 \times 2$ & $4.84 \times 2$ & $4.09 \times 2$ \\
OI S OI & 0.014 & 4.74 & 3.31 \\
\hline
\end{tabular}

Where: $S=$ Stearic acid

S.O. = Soic acid

Table III

2-mono-olein with stearin at 1-and/or 3-positions percentages

\begin{tabular}{cccc}
\hline $\begin{array}{c}\text { Type of } \\
\text { glycerides }\end{array}$ & Control & $\begin{array}{c}\text { S.0. interesterified } \\
\text { for } 4 \text { hours } \\
\text { at } 90^{\circ} \mathrm{C} \text { with } 0.4 \% \\
\text { nickel catalyst }\end{array}$ & $\begin{array}{c}\text { S.0. interesterified } \\
\text { for } 4 \text { hours } \\
\text { at } 90^{\circ} \mathrm{C} \text { with } 0.6 \% \\
\text { nickel catalyst }\end{array}$ \\
\hline OI OI OI & 1.48 & 8.34 & 5.62 \\
OI OI S & $0.045 \times 2$ & $8.53 \times 2$ & $6.95 \times 2$ \\
S OI S & 0.051 & 8.72 & 8.59 \\
\hline
\end{tabular}

Where: $S=$ Stearic acid

$\mathrm{OI}=$ Oleic acid

Table IV

2-mono-linolein with linolenolein at 1-and/or 3-positions percentages

\begin{tabular}{cccc}
\hline $\begin{array}{c}\text { Type of } \\
\text { glycerides }\end{array}$ & Control & $\begin{array}{c}\text { S.0. interesterified } \\
\text { for } 4 \text { hours } \\
\text { at } 90^{\circ} \mathrm{C} \text { with } 0.4 \% \\
\text { nickel catalyst }\end{array}$ & $\begin{array}{c}\text { S.0. interesterified } \\
\text { for } 4 \text { hours } \\
\text { at } 90^{\circ} \mathrm{C} \text { with } 0.6 \% \\
\text { nickel catalyst }\end{array}$ \\
\hline Ln Ln Ln & 5.11 & 0.02 & 0.025 \\
Len Ln Ln & $0.39 \times 2$ & $0.004 \times 2$ & $0.1 \times 2$ \\
Len Ln Len & 0.03 & 0.001 & 0.008 \\
\hline
\end{tabular}

Where: $L n=$ Linoleic acid

Len $=$ Linolenic acid
Table V

2-mono-linolenolein with linolein at 1-and/or 3-positions percentages

\begin{tabular}{lccc}
\hline $\begin{array}{c}\text { Type of } \\
\text { glycerides }\end{array}$ & Control & $\begin{array}{c}\text { S.0. interesterified } \\
\text { for } 4 \text { hours } \\
\text { at } 90^{\circ} \mathrm{C} \text { with } 0.4 \% \\
\text { nickel catalyst }\end{array}$ & $\begin{array}{c}\text { S.0. interesterified } \\
\text { fo } 4 \text { hours } \\
\text { at } 90^{\circ} \mathrm{C} \text { with } 0.6 \% \\
\text { nickel catalyst }\end{array}$ \\
\hline Len Len Len & 0.02 & 0.001 & 0.007 \\
Len Len Ln & $0.27 \times 2$ & $0.005 \times 2$ & $0.11 \times 2$ \\
Ln Len Ln & 3.6 & 0.015 & 0.023 \\
\hline
\end{tabular}

Where: $\operatorname{Ln}=$ Linoleic acid

Len $=$ Linolenic acid

Table VI

Weight percentage of triglycerides of soybean oil and interesterified soybean oil percentages at $90{ }^{\circ} \mathrm{C}$ for four hours stirring using nickel catalyst



Generally, an interesterification of soybean oil using $0.4 \%$ nickel catalyst give the proper stability to the oil. So from the economical point of view it is more practical in application.

\section{REFERENCES}

1. Macrae, A.R. (1983).- «Lipase catalyzed interesterification of oils and fats".- Journal of the American Oil Chemists'Society 60, 291.

2. Wisdom, R.A., Dunnill, P. y Lilly, M.D. (1987).«Enzymatic interesterification of fats: Laboratory and pilot-scale studies with immobilized lipase from Rhizopus arrhizus».-Biotechnol. Bioeng. 29 (9) 1081-1085.

3. Kurashige, J., Matsuzaki, N. y Takahashi, H. (1993).«Enzymatic modification of canola/palm oil mixtures; effects on the fluidity of the mixture".-Journal of the American Oil Chemists'Society 70 (9) 849-852.

4. Basheer, Sobhi., Mogi, Ken-ichi y Nakajima, Mitsutoshi (1995). - «Interesterification kinetics of triglycerides and fatty acids with modified lipase in n-hexane".Journal of the American Oil Chemists'Society 72 (5) 511-518.

5. $\mathrm{Zu}, \mathrm{Yi} \mathrm{Li} \mathrm{y} \mathrm{Ward,} \mathrm{O.P.} \mathrm{(1993).—-Lipase-catalyzed}$ esterification of glycerol and $\mathrm{n}^{-3}$ polyunsaturated fatty acid concentrate in organic solvent".- Journal of the American Oil Chemists'Society 70 (8) 745-748. 
6. Casimir Chike, Akoh, Cooper, C y Nwosu, C.V. (1992)."Lipase $G$ catalyzed synthesis of monoglycerides in organic solvent and analysis by HPLC».-Journal of the American Oil Chemists'Society 69 (3) 257-260.

7. Sil Roy, S y Bhattacharyya, D.K. (1993).-- «Detection of interesterified fat in hydrogenated fat by lipase hydrolisis and by cooling curve analysis".- Journal of the American Oil Chemists'Society 70 (9) 923-925.

8. Masahiro Goto., Munehara Goto, Noriho Kamiya y Fumiyuki Nakashio (1995)._- «Enzymatic interesterification of triglyceride with surfactant-coated lipase in organic media".-J. Biotechnology and Bioeng. 45 27-32.

9. Mattson, F.H. y Lutton, E.S. (1958).- «Specific distribution of fatty acids in glycerides of animal and vegetable fats".-J. Biol. Chem. 233, 868-871.

10. Scott Bloomer, Patrick Adlercreutz y Bo Mattiasson (1990). - «Triglyceride interesterification by lipase 1 Cocoa butter equivalents from a fraction of palm oil'.- Journal of the American Oil Chemists'Society 67 (8).

11. Sil Roy, S. y Bhattacharyya, D.K. (1993)._- «Distinction between enzymatically and chemically catalyzed interesterification".-Journal of the American Oil Chemists'Society 70 (12) 1293-1294.

12. Mangold, H.K. (1969).- Thin-layer chromatography, Edited by E. Stahl, Springer-Verlag, Berlin Heidelberg, New York, p. 1961.

13. Metcalfe, L.D. y Schmitz, A.A. (1961).-«Preparation of fatty acid esters for gas -chromatographic analysis».-Anal. Chem. 33, 363.

14. Coleman, M.H. y Fulton, W.C. (1961).-«Enzymes and lipid metabolism".-Edited by P. Desnuelle, Pergamon Press, p. 127.

15. Van der Wal, R.J. (1960)- - "Calculation of the distribution of the saturated and unsaturated acyl groups in fats, from pancreatic lipase hydrolysis data".- Journal of the American Oil Chemists'Society 37, 18.

16. Gunstone, F.D. (1962)._- «Distribution of fatty acids in natural glycerides of vegetable origin".- Chem. And. Ind. (London), p. 1214

17. Youngs, C.G. (1959).- - «Glyceride structure of fats».Journal of the American Oil Chemists'Society 30, 326.

18. Kartha, A.R.S. (1953).- - -The glyceride structure of natural fats. II. The rule of glyceride type distribution of natural fats".- -Journal of the American Oil Chemists' Society 36, 664 .

19. Kartha, A.R.S. (1954).— -Natural fats. XI. The restricted random distribution rule and glyceride structure of the more natural fats».-J. Sci. Ind. Res. (India 13a, 471)

20. Kartha, A.R.S. (1959).- -Configuration of natural mixed glycerides according to the restricted random distribution rule».-J. Sci. Ind. Res. 18A, 304.

21. Kartha, A.R.S. (1962).- «Glyceride type distribution rule calculations".- Journal of the American Oil Chemists'Society 39, 272.

22. Lortie, R.M. Trani y Ergan, F. (1993).-«Kinetic study of the lipase - catalyzed synthesis of triolein".Biotech. Bioeng. 41, 1021.

23. Heisler, A., Rabiller, C. y Hublin (1991).- -Lipase catalyzed isomerization of $1,2-(2,3)$-diglyceride into 1,3-diglyceride. The crucial role of water".Biotechnol. Lett. 13 (5) 327-332. 